\title{
KEARIFAN LOKAL TRADISI UYEN SAPI PERAJUT INTEGRASI SOSIAL (STUDI KASUS DI DESA JONGGOL KECAMATAN JAMBON KABUPATEN PONOROGO)
}

\author{
Yudi Hartono \\ Dewi Setiana *)
}

\begin{abstract}
Abstrak
Penelitian ini bertujuan untuk mendeskripsikan secara mendalam tentang prosesi, makna simbolis, fungsi, dan pelestarian tradisi Uyen Sapi di Desa Jonggol Kecamatan Jambon Kabupaten Ponorogo sebagai bentuk kearifan masyarakat lokal dalam merajut integrasi sosial. Jenis penelitian deskriptif kualitatif. Sumber data terdiri dari sumber primer dan sekunder. Data primer berupa informasi dari warga masyarakat, kepala desa, tokoh adat, dan tokoh agama. Sumber sekunder berupa bahan pustaka dengan kualifikasi tinggi untuk melengkapi data primer. Data dikumpulkan dengan teknik observasi, wawancara mendalam, mencatat dokumen dan arsip. Validitas data diperoleh melaui trianggulasi sumber, dan teknik. Analisis data yang digunakan adalah analisis interaktif.

Hasil penelitian menunjukkan bahwa tradisi Uyen Sapi dilaksanakan pada hari Jumat Wage Wuku Wuye. Hari tersebut dianggap hari kelahiran sapi. Prosesi diawali dengan ikrar hajat oleh tokoh adat dalam Bahasa Jawa, dilanjutkan doa oleh tokoh agama dalam Bahasa Arab; pembagian bahanbahan selamatan secara merata kepada warga yang diundang, termasuk warga yang tidak bisa datang; dan terakhir pemberian minuman dawet kepada sapi di kandang. Bahan-bahan selamatan mengandung makna simbolik tersendiri. Makna simbolik tersebut tidak lepas dari ekspresi harapan dan doa syukur, keselamatan, dan keberkahan rizki yang diberikan Tuhan. Tradisi tersebut menjadi media bagi masyarakat dalam merajut integasi sosial. Tradisi Uyen Sapi dilestarikan oleh masyarakat yang bersangkutan dan melibatkan pemerintah daerah setempat.
\end{abstract}

Kata kunci: tradisi, kearifan lokal, integrasi sosial

\section{Pendahuluan}

Masyarakat Indonesia merupakan masyarakat majemuk dengan berbagai macam corak kebudayaan. Kebudayaan Indonesia tidak lepas dari pertemuan berbagai unsur kebudayaan, antara lain HinduBudha dan Islam. Harbangun (1986:56)

\footnotetext{
* Yudi Hartono, Dosen Pendidikan Sejarah IKIP PGRI MADIUN

Dewi Setiana, Mahasiswa Pendidikan Sejarah IKIP PGRI MADIUN
}

52|Agastya Vol. 02 No. 01 Januari 2012 
menyebutkan masuknya agama Hindu dan Budha ke Indonesia dibawa oleh pedagangpedagang dari India sejak abad permulaan Masehi. Hubungan itu terjalin melalui dua jalur, yaitu jalur darat melalui Tibet dan jalur laut melalui Selat Malaka. Kebudayaan asli Indonesia yang masih sangat sederhana bertemu dengan kebudayaan Hindu dan Budha yang semakin meluas dan dianut oleh banyak masyarakat di Indonesia. Hal ini dapat dilihat di berbagai kerajaan yang pernah ada di wilayah Barat dan Tengah Indonesia yang menganut agama tersebut seperti Kutai, Tarumanegara, Sriwijaya, Pajajaran, dan Majapahit. Pada masa kerajaan Majapahit Indonesia mencapai kebersamaannya dengan menyatukan kerajaan yang ada di wilayah Nusantara oleh Raja Hayam Huruk dengan Patih Gajah Mada yang terkenal dengan Sumpah Palapanya.

Kesatuan tersebut menjadikan kebudayaan Indonesia semakin menunjukkan dinamikanya. Keadaan ini semakin terlihat ketika agama Islam mulai banyak dianut oleh masyarakat di Indonesia. Sebelum Islam masuk dan berkembang, Indonesia sudah memiliki corak kebudayaan yang dipengaruhi oleh agama Hindu dan Budha. Masuknya Islam kebudayaan Indonesia mengalami proses akulturasi, yang melahirkan kebudayaan baru, yaitu kebudayaan Islam Indonesia.

Surutnya pengaruh agama Hindu di Indonesia semakin memudahkan agama Islam untuk masuk dan berkembang. Proses masuk dan berkembangnya agama Islam di Indonesia terdapat tiga teori, yaitu teori Gujarat, teori Mekah, dan teori Persia. Masuknya kebudayaan Islam tersebut tidak berarti kebudayaan Hindu dan Budha hilang, akan tetapi kedua kebudayaan tersebut mengalami akulturasi. Akulturasi tidak hanya bersifat kebendaan, tetapi juga menyangkut perilaku masyarakat, seperti halnya perilaku masyarakat penganut agama Hindu dalam menyikapi binatang yang dianggap suci.

Menurut Sihombing (1962:39), dari semua binatang, lembu atau sapi adalah binatang yang paling suci. Semua yang berasal dari sapi dianggap suci. Seorang Hindu yang alim tidak akan melintasi jalannya seekor sapi, jika tidak lebih dahulu menyapu kepala sapi itu sebagai tanda hormatnya. Memberi makan seekor sapi dipandang suatu jasa besar. Selain di dunia ini, di kayangan pun sapi itu mendapat tempat yang mulia. Sapi dan Brahmana telah diciptakan oleh Brahma. Membunuh seekor sapi sama besarnya dengan membunuh seorang Brahmana.

Binatang sapi diistimewakan. Di Ponorogo, tepatnya di Desa Jonggol Kecamatan Jambon, muncul tradisi untuk menghormati tradisi leluhur terhadap binatang sapi. Tradisi tersebut disebut dengan Uyen Sapi yang sampai saat ini masih terus dilestarikan. Tradisi ini menarik untuk diteliti terkait dengan prosesi, makna simbolis, pelestarian, dan fungsinya bagi masyarakat pendukung tradisi tersebut.

\section{Tujuan dan Manfaat Penelitian}

Tujuan penelitian ini sebagai berikut.

1. Mendeskripsikan prosesi tradisi Uyen Sapi di Desa Jonggol Kecamatan Jambon Kabupaten Ponorogo.

2. Mengungkap makna simbolis tradisi Uyen Sapi di Desa Jonggol Kecamatan Jambon Kabupaten Ponorogo.

3. Mengungkap upaya pelestarian tradisi Uyen Sapi di Desa Jonggol Kecamatan Jambon Kabupaten Ponorogo.

4. Mengungkap fungsi tradisi Uyen Sapi di Desa Jonggol Kecamatan Jambon Kabupaten Ponorogo sebagai media dalam merajut integasi sosial. 
Penelitian ini diharapkan dapat bermanfaat sebagai berikut :

1. Memperluas wawasan berpikir dan nomenklatur kebudayaan masyarakat Indonesia

2. Memberi informasi kepada masyarakat luas tentang budaya luhur bangsa Indonesia yang harus dijaga dan dilestarikan.

3. Menjadi masukan bagi pemerintah daerah dalam mengambil kebijakan strategi kebudayaan di tingkat lokal.

4. Menambah referensi dan pengembangan keilmuan Program Studi Pendidikan Sejarah IKIP PGRI MADIUN.

\section{Tinjauan Pustaka}

\section{Tradisi}

Menurut Sztompka (2008:69) tradisi adalah keseluruhan benda material dan gagasan yang berasal dari masa lalu namun benar-benar masih ada, belum dihancurkan, dirusak, dibuang atau dilupakan. Tradisi mencakup kelangsungan masa lalu dan masa kini. Kelangsungan masa lalu di masa kini mempunyai dua bentuk material dan gagasan.

Tradisi atau kebiasaan juga sering disebut dengan adat istiadat. Adat istiadat adalah perbuatan sosial yang merupakan jaringan cita-cita, norma-norma, aturan, kaidah, pandangan, sistem dan sebagainya. Kebiasaan yang sudah tradisional dijadikan normatif, maka berubahlah ia menjadi adat, dan adat yang sudah mendarah daging membentuk tabiat (Gazalba, 1974:39).

Berdasarkan uraian di atas dapat disimpulkan bahwa tradisi atau adat istiadat merupakan kebiasaan turun temurun yang diwariskan oleh generasi ke generasi terdahulu yang masih dilakukan oleh masyarakat baik berupa benda material maupun gagasan secara tidak tertulis sebagai kontrol atas tingkah laku atau sikap manusia sebagai warga suatu masyarakat.

Fungsi tradisi dibedakan ke dalam empat hal, yaitu: 1) tradisi adalah kebijakan turun-temurun, tempatnya di dalam kesadaran, keyakinan, norma, dan nilai yang dianut serta benda yang diciptakan di masa lalu; 2) memberi legitimasi dalam pandangan hidup, keyakinan, pranata dan aturan yang sudah ada; 3) menyediakan simbol identitas kolektif yang meyakinkan, memperkuat loyalitas primordial terhadap bangsa, komunitas dan kelompok; dan 4) membantu menyediakan tempat pelarian dari keluhan ketidakpuasan, dan kekecewaan kehidupan modern. Tradisi mengesankan masa lalu yang lebih bahagia, menyediakan sumber pengganti kebanggaan apabila masyarakat berada dalam kritis (Sztompka, 2008: 74).

Koentjaraningrat dalam Herusatoto (2008:164) membagi dalam empat tingkatan yaitu tingkat nilai budaya, berupa ide-ide yang mengkonsepsikan hal-hal yang paling bernilai dalam kehidupan masyarakat, dan biasanya berakar dalam bagian emosional dan alam jiwa manusia, misalnya gotong royong atau sifat suka kerjasama berdasarkan solidaritas yang besar. Tingkat normanorma, berupa nilai-nilai budaya yang sudah terkait kepada peranan masing-masing anggota masyarakat dalam lingkungannya. Tingkat hukum, sistem hukum yang berlaku seperti hukum adat perkawinan dan hukum adat kekayaan. Tingkat aturan khusus, yang mengatur kegiatan-kegiatan yang jelas terbatas ruang lingkupnya dalam masyarakat dan sifatnya konkrit, misalnya aturan sopan santun.

Tradisi penting untuk dilestarikan. Upaya pelestarian tradisi dapat dibagi ke dalam dua faktor yaitu faktor intern dan faktor ekstern. Faktor intern merupakan faktor dari dalam masyarakat sendiri, yaitu pelestarian yang dilakukan oleh masyarakat karena adanya rasa takut apabila tidak 
menjalan sebuah tradisi akan membawa dampak buruk bagi kehidupan mereka. Sedangkan faktor ekstern adalah dari lembaga pemerintahan terutama pemerintah daerah, dalam hal mendukung setiap kegiatan masyarakat dalam rangka melestarikan budaya lokal.

\section{Kearifan Lokal}

Kearifan secara etimologis berarti kemampuan seseorang dalam menggunakan akalnya untuk menyikapi suatu kejadian, objek atau situasi. Sedangkan lokal menunjukkan ruang interaksi dimana peristiwa atau situasi itu trjadi. Kearifan lokal didefinisikan sebagai kebenaran yang mentradisi atau ajeg dalam suatu daerah (Gobyah, 2003). Kearifan lokal dapat dipahami sebagai usaha manusia dengan menggunakan akalnya untuk bertindak dan bersikap terhadap sesuatu, objek, atau peristiwa yang terjadi dalam ruang tertentu (Ridwan, 2007).

Kearifan lokal masyarakat (local wisdom) sudah ada di dalam kehidupan masyarakat semenjak zaman dahulu mulai dari zaman pra-sejarah hingga saat ini, kearifan lingkungan merupakan perilaku positif manusia dalam berhubungan dengan alam dan lingkungan sekitarnya yang dapat bersumber dari nilai-nilai agama, adat istiadat, petuah nenek moyang atau budaya setempat (Wietoler, 2007).

Kearifan lokal terbangun secara alamiah dalam suatu komunitas masyarakat untuk beradaptasi dengan lingkungan di sekitarnya, perilaku ini berkembang menjadi suatu kebudayaan di suatu daerah dan akan berkembang secara turun-temurun, secara umum, budaya lokal atau budaya daerah dimaknai sebagai budaya yang berkembang di suatu daerah, yang unsur-unsurnya adalah budaya suku-suku bangsa yang tinggal di daerah itu.

Dengan demikian, kearifan lokal secara substansial merupakan norma yang berlaku dalam suatu masyarakat yang diyakini kebenarannya dan menjadi acuan bertindak dan berperilaku sehari-hari. Oleh karena itu, kearifan lokal merupakan entitas yang sangat menentukan harkat dan martabat manusia dalam komunitasnya (Geertz, 2007). Bentuk kearifan lokal dapat dibedakan ke dalam dua aspek, yaitu aspek yang berwujud (tangible) dan aspek yang tidak berwujud (intangible). Sedangkan jenis kearifan lokal meliputi kelembagaan, nilai adat, serta tata cara dan prosedur termasuk dalam pemanfaatan ruang.

\section{Integrasi Sosial}

$\mathrm{Di}$ negara yang masyarakatnya bercorak majemuk seperti Indonesia, pengetahuan tentang interaksi sosial yang terjadi antara satu kelompok masyarakat dengan kelompok masyarakat lain menjadi penting. Dengan mengetahui dan memahami kondisi yang dapat menimbulkan serta mempengaruhi bentuk interaksi sosial tertentu, maka pengetahuan tersebut dapat disumbangkan bagi usaha pembinaan bangsa dan masyarakat (Soekanto, 1982:54). Menurut Young (dalam Soekanto, 1982:54), interaksi sosial adalah kunci dari semua kehidupan sosial, karena tanpa itu tak ada kehidupan sosial.

Dalam kedudukannya sebagai mahluk sosial, manusia cenderung untuk selalu berhubungan dengan lingkungannya. Terjadinya interaksi sosial selalu didahului oleh suatu kontrak sosial dan komunikasi (Susanto, 1979). Interaksi sosial dalam artian umum dimaksudkan sebagai hubungan sosial yang dinamis yang menyangkut hubungan antar perorangan, antar kelompok, dan antara perorangan dengan kelompok manusia (Soekanto, 1982:55).

Integrasi merupakan proses penyesuaian di antara unsur-unsur yang saling berbeda dalam kehidupan sosial, sehingga menghasilkan suatu pola kehidupan yang 
serasi bagi masyarakat tersebut. Para penganut paham pendekatan konflik, menyatakan bahwa suatu integrasi dapat terwujud atas adanya coercion (paksaan) dari suatu kelompok/satuan sosial dominan terhadap kelompok/satuan kelompok lain, atau pun adanya saling ketergantungan di bidang ekonomi antara berbagai kelompok/satuan sosial yang ada dalam masyarakat.

Integrasi sosial dapat terbentuk apabila para anggota masyarakat bersepakat mengenai stuktur kemasyarakatan, nilai-nilai, dan norma serta pranata sosial yang berlaku dalam masyarakat tersebut. $\mathrm{Di}$ samping itu juga diperlakukan adanya kesepakatan mengenai batas teretorial/ wilayah yang jelas akan tempat yang mereka tinggali. William F. Ogburn dan Mayer Nimkoff mengemukakan tentang syarat berhasilnya suatu integrasi sosial yaitu: (1) Kemampuan untuk mengisi kebutuhan anggota masyarakat satu dengan lainnya, sehingga terjalin hubungan yang baik dan saling menjaga keterikatan satu dengan yang lain; (2) Keberhasilan menciptakan kesepakatan mengenai norma dan nilai-nilai sosial sebagai pedoman dalam menjalin interaksi satu dengan yang lain; (3) Nilai-nilai dan norma-norma sosial tersebut berlaku dalam waktu yang cukup lama dan telah dilaksanakan secara konsisten.

\section{Metode Penelitian}

Penelitian ini termasuk jenis penelitian deskriptif kualitatif. Lokasi penelitian di Desa Jonggol Kecamatan Jambon Kabupaten Ponorogo, kurang lebih 17 km ke arah Selatan dari pusat kota Ponorogo. Penelitian dilakukan selama empat bulan dari bulan Pebruari sampai dengan Mei 2011.
Sumber data dalam penelitian terdiri dari sumber primer dan sekunder. Data primer dalam penelitian ini berupa informasi dari Kepala Desa, warga masyarakat baik generasi tua maupun generasi muda, tokoh adat, dan tokoh agama di Desa Jonggol Kecamatan Jambon Kabupaten Ponorogo. Sumber sekunder diperoleh dari bahan kepustakaan melengkapi data primer.

Data dikumpulkan dengan teknik observasi, wawancara mendalam dan dokumentasi. Observasi dilakukan terhadap prosesi tradisi Uyen Sapi. Wawancara dilakukan dengan kepala desa, tokoh adat, tokoh agama dan warga masyarakat baik generasi tua maupun muda. Pemilihan informan dilakukan secara selektif berdasarkan pengetahuan tentang tradisi Uyen Sapi dan partisipasi dalam tradisi Uyen Sapi. Adapun dokumen yang digunakan dalam penelitian ini berupa profil desa dan bahan pustaka yang relevan.

Validitas data diperoleh melaui trianggulasi sumber dan teknik, yaitu dengan membandingkan data dari suatu sumber dengan sumber lainnya dan teknik yang satu dengan teknik lain. Analisis data yang digunakan adalah analisis interaktif, yaitu proses analisis dimana peneliti tetap bergerak diantara tiga komponen (reduksi data, sajian data dan penarikan simpulan/ verifikasi) dengan proses pengumpulan data selama kegiatan pengumpulan data berlangsung (Sutopo, 2006:119). Langkah analisis data dapat disajikan dalam bagan sebagai berikut.

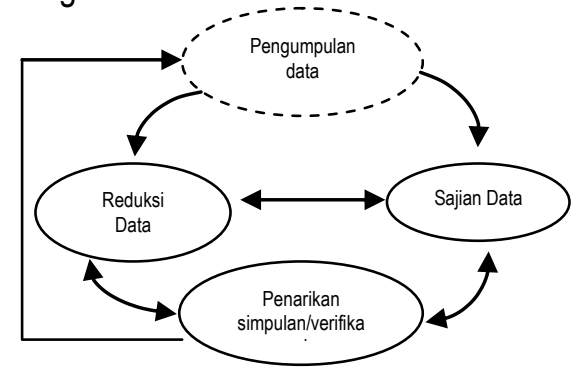


Bagan Model Analisis Interaktif

\section{Hasil Penelitian}

\section{Asal Usul Desa Jonggol}

Berdasarkan sumber data yang ditersedia di kantor desa, Desa Jonggol ada sebelum tahun 1945. Kata Jonggol sendiri berasal kata Janggala yang dalam Kamus Besar Bahasa Jawa Kuno-Indonesia (Depdikbud, 2006:413) berarti jarang ditumbuhi dengan pepohonan dan tumbuhan sekalipun tidak gersang, tertutup dengan hutan, tanah yang tidak digarap.

Ada beberapa versi tentang sejarah Desa Jonggol. Versi pertama dari cerita seseorang bernama Mbah Enggot yang membuka lahan sangat luas dengan menebas alang-alang. Mbah Enggot dianggap orang sakti sehingga sangat dihormati pada waktu itu. Kemanapun Mbah Enggot pergi ia selalu membawa tongkat. Pada suatu hari tongkat tersebut ditancapkan ke dalam tanah dan tongkat tersebut kemudian tumbuh menjadi pohon beringin yang besar dan dianggap sebagai pohon keramat. Setiap ada hajatan atau acara di desa tersebut selalu diberi sesaji untuk Mbah Enggot yang diletakkan di bawah pohon beringin tersebut. Pertumbuhan penduduk karena banyaknya pendatang menjadikan pohon tersebut dianggap mengganggu sehingga ditumbangkan. Karena keberadaan pohon beringin tersebut, maka daerah tersebut dinamakan Dukuh Ringin yang termasuk wilayah Desa Jonggol (Wawancara dengan Sikat, 13 Pebruari 2011).

Versi lain berasal dari cerita sebuah sumur yang kemunculannya secara tiba-tiba. Sumur tersebut dianggap keramat dan keberadaannya terkadang bisa dilihat seperti sumur dan terkadang tertutup rata oleh tanah. Pada zaman dahulu sumur tersebut sering dijadikan orang sebagai tempat nyepi untuk mendapatkan wangsit (Wawancara dengan Jemitun,13 Pebruari 2011). Keberadan pohon beringin dan sumur keramat dalam cerita sejarah Desa Jonggol tersebut sampai saat ini sulit dibuktikan secara fisik sebab peninggalannya atau sisa-sisanya tidak ditemukan.

Secara geografis letak desa Jonggol berada di wilayah selatan Kabupaten Ponorogo Jawa Timur. Desa Jonggol di sebelah selatan berbatasan dengan Desa Karang Patihan Kecamatan Balong, sebelah utara dan barat berbatasan dengan perhutani Gunung Krasak, dan timur berbatasan Dengan desa Ngumpul Kecamatan Balong.

Jumlah penduduk di desa Jonggol tercatat 3.454 jiwa. Jumlah penduduk berdasarkan jenis kelamin yaitu laki-laki 1.806 jiwa, perempuan 1.648 jiwa dengan 980 kepala keluarga yang terbagi ke dalam 23 RT dan 08 RW dan dua bagian Dukuh, yaitu Dukuh Lor (09 RT) dan Dukuh Kidul (14 RT). Hasil pertanian di Desa ini adalah padi dan palawija, diantaranya: kacang tanah, jagung, ubi kayu, dan terong. Buahbuahan yang banyak dihasilkan adalah jeruk dan mangga.

Desa Jonggol dipimpin oleh seorang Kepala Desa. Tugas Kepala Desa sebagai pimpinan dari seluruh warga yang dipilih melalui pemilihan Kepala desa. Sekretaris Desa sebagai perangkat di bawah Kepala Desa menjalankan fungsi administrasi pemerintahan, pembangunan dan kemasyarakatan, pelaksana surat menyurat, kearsipan dan laporan, serta pelaksana urusan keuangan. Dalam melaksanakan tugasnya dibantu oleh kaur Sekretariat Desa yang melaksanakan tugas lain yang diberikan oleh Kepala Desa.

Bayan sebagai pelaksana perintah kepala desa tugasnya berhubungan dengan masyarakat, melaksanakan tugas lain yang 
diberikan Kepala Desa. Jogoboyo sebagai Pembina dan menjaga ketentraman, keamanan dan ketertiban Desa, mengambil langkah-langkah penanggulangan dalam hal terjadi bencana alam, dan melaksanakan tugas lain yang diberikan Kepala Desa. Sambong sebagai pengatur dan pengambil langkah-langkah tersedianya kebutuhan air bagi petani, mengurus organisasi petani dalam pemakaian air, mengatur kegiatan pemeliharaan saluran air, menyusun rencana dan program dalam rangka penerapan teknologi tepat guna pertanian, dan melaksanakan tugas lain yang diberikan Kepala Desa.

Modin sebagai pelaksana tugas yang berkaitan dengan bidang keagamaan dan sosial kemasyarakatan, serta tugas lain yang diberikan Kepala Desa. Kamituwol wakil dukuh, melaksanakan sebagian tugas Kepala Desa di wilayah kerjanya, pelaksana kegiatan pemerintahan, pembangunan, kemasyarakatan, ketertiban di wilayah kerjanya, pelaksana kebijakan kepala desa di wilayah kerjanya, serta melaksanakan tugas lain yang diberikan kepala Desa. (Wawancara dengan Sutrisno, 13 Mei 2011).

Institusi adat di Desa Jonggol yaitu musyawarah adat, perkawinan adat, upacara kematian secara adat, upacara pernikahan secara adat, upacara adat dalam kegiatan pertanian/peternakan, dan upacara adat dalam membangun rumah. Tradisi Uyen Sapi termasuk ke dalam upacara adat dalam kegiatan pertanian/peternakan.

\section{Prosesi Tradisi Uyen Sapi}

Perhitungan kalender Jawa mengenal harian dari Akad, Senen, Selasa Rebo, Kemis, Jumuah, Setu dan hari pasaran yaitu Kliwon, Legi, Pahing, Pon, Wage, untuk perhitungan Wuku yaitu Sinta, Landhep, Wukir, Kurantil, Tolu, Gumbreg, Warigalit, Wariagung, Julungwangi, Sungsang, Gelungan, Kuningan, Langkir, Mandhasia,
Julungpujut, Pahang, Kerewelut Marakeh, Tambir, Mandhangkungan, Maktal, Wuye,Manail, Prangbakat, Bala, Wugu, Wayang, Kulawu, Dhukut, Watugunung, dan untuk bulan yaitu Sura, Sapar, Robingulawal, Robingulakir, Jumadilawal, Jumadilakir, Rejeb, Ruah, Pasa, Sawal, Dulkaidah, Besar (Soemodidjojo,2008: 7).

Tradisi Uyen Sapi dilakukan pada hari Jumat Wage Wuku Wuye karena pada hari tersebut dianggap sebagai hari kelahiran sapi (Wawancara dengan Jiran, 28 Pebruari 2011). Adapun tahap-tahap prosesnya sebagai berikut.

Kegiatan awal adalah persiapan bahan-bahan. Bahan-bahan tersebut berupa makanan yang dikerjakan secara gotong royong terutama oleh kaum perempuan. Bahan-bahan untuk acara selamatan diantaranya sebagai berikut.

1) Sego gurih dan ingkung

Sego gurih adalah nasi yang dibumbui dengan santan dan garam atau lebih dikenal dengan nasi uduk. Sedangkan ingkung yaitu ayam kampung yang diberi bumbu-bumbu dan dikukus. Keduanya diletakkan dalam satu wadah dengan urutan sego gurih berada di bawah kemudian ingkung di atasnya.

2) Sego golong

Sego golong adalah nasi putih yang dibentuk golong-golong (bulat-bulat), dibentuk dengan beberapa jumlah berdasarkan tujuannya. Golong 2 simbol siang dan malam, golong 5 simbol Pasaran Jawa, golong 7 simbol hari Jawa, golong 9 simbol wali songo.

3) Buceng kuat

Buceng kuat adalah nasi puth yang dibentuk layaknya gunung (meruncing ke atas).

4) Jenang abang/sengkolo

Jenang abang/sengkolo adalah tepung beras dimasak dan diberi gula merah. 


\section{5) Brokohan}

Brokohan adalah nasi putih dengan sayur dan lauk pauk di atasnya. Disebut brokohan agar mendapatkan berkah dari Tuhan Yang Maha Esa.

6) Sayur kluwih

Sayur kluwih adalah sayuran kluwih atau cempedak yang diberi bumbu dan santan kelapa.

7) Dawet

Dawet adalah jenis minuman yang memiliki butiran-butiran di dalamnya, dengan bahan-bahan alami, rasanya manis dan menyegarkan.

Seluruh persiapan tersebut disiapkan oleh warga yang melakukan tradisi Uyen Sapi dengan dibantu oleh para tetangga, terutama kaum perempuan. Dalam sekali Uyen Sapi menghabiskan dana sekitar Rp. 175.000.00 - Rp. 200.000,00 (Wawancara dengan Tukiyem, 25 Pebruari 2011).

Setelah Magrib diundang warga sekitar/tetangga untuk menghadiri acara selamatan/kenduri. Mengambil waktu magrib karena menyesuaikan dengan jadwal kehidupan masyarakat petani yang rata-rata bekerja dari pagi hingga sore hari di sawah. Banyaknya warga yang diundang sekitar 1015 orang. Setelah tamu undangan berkumpul dan duduk lesehan di tikar agar lebih nyaman karena berbagai makanan yang bermacam-macam sehingga memakan banyak tempat. Selanjutnya dikeluarkan seluruh perangkat selamatan yang disebut dengan asahan yaitu seluruh makanan yang diperlukan dalam slametan.

Pihak yang mempunyai hajat menyampaikan maksud dari acara selamatan kepada tukang hajat yaitu tokoh adat. Tokoh adat mengucapkan ikrar hajat dalam bahasa Jawa sebagai Berikut :

Maklum sedoyo mawon, kulo naming sedremi ngikraraken kajatipun bapak anggenipun graket sekul suci ulam sari caos pepenget dumateng kanjeng nabi Mohamad
SAW, soho kanjeng nabi rosul sekabat, segarwo, seputra, pramilo ujub ipun manah mbok bilih dumugi akhiripun jaman pikantuk safaat ipun saking kanjeng nabi Mohamad SAW. Anggenipun ngrakit golong limo memule anggenipun ikal sarto bakal karang pamahan mriki kinlat sekawan, gangsal pancer, enem pangongsan, pitu paugerane dukuh mriki. Anggenipun ngrakit golong pitu nyumerepi pekenan gangsal rangkepe dinten pitu uku tigang ndoso tahun wolu windu sekawan. Anggenipun ngrakit golong songo nyumerepi dumateng poro nabi, poro wali, ingkang kagungan syariat kagem nyariati anggenipun ngelampahi Uyen bapak...mugi sageto babar pinangkar rojo koyone bapak...Anggenipun ngrkit sego brokohan , mugi-mugi barokahi dumateng bapak...ingkang kagungan kajat Anggenipun ngrakit buceng kuat jejek langgeng selamilamine bapak...Anggenipun ngrakit jenang sengkolo, nyengkalani anggenipun Uyen ngebihno godo kencono nyelahne kawilujengan bapak...(Wawancara dengan Jiran, 06 Mei 2011).

(Mohon maaf sebelumnya, saya hanya mewakili mengucapkan hajat dari bapak... Tujuan dirakitnya nasi suci dan lauk ditujukan kepada Nabi Muhammad SAW, sahabat Rasul, istri Rasul, dan anakanak Rasul. Dengan niatan dihati semoga diakhir jaman mendapat perlindungan dari nabi Muhammad SAW. Ttujuan dirakitnya golong lima mengingatkan asal mula pekarangan rumah yang ditempati yang memiliki empat titik utara,selatan,timur,barat dan kelima adalah pusat rumah, enam tempat pengambilan air, tujuh tata cara dukuh adapt setempat. Tujuan dirakitnya golong sembilan mengingatkan kepada para nabi, para wali, yang mempunyai keagungan syariat untuk mensyariati keluarga yang melakukan Uyen Sapi, semoga dapat berkembang biak menjadi banyak. Tujuan 
dirakitnya buceng kuat semoga kuat,teguh,abadi selama-lamanya. Tujuan dirakitnya golong tujuh melambangkan hari pasaran, lengkap dengan tujuh hari, wuku tiga puluh, tahun delapan dan empat windu. Tujuan dirakitnya nasi brokohan, semoga memberikan barokah terhadap keluarga bapak... yang mempunyai hajat. Tujuan dirakitnya jenang sengkolo, memperingati uyen, menjauhkan cobaan, dan mendekatkan keselamatan bapak...).

Setelah diikrarkan dalam bahasa Jawa dilanjutkan pembacaan doa selamat oleh tokoh agama setempat. Doa diucapkan dalam Bahasa Arab. Selanjutnya bahanbahan selamatan dibagikan seluruh asahan dengan rata, termasuk bagi warga yang tidak bisa datang. Setelah selesai dan makanan sudah diberi doa, maka diambilkan sedikit dari minuman dawet untuk diberikan kepada sapi yang berada di kandang, dengan harapan akan membawa berkah dan mendatangkan banyak rejeki. (Observasi, 7 Mei 2011). Banyaknya warga yang masih melakukan tradisi ini, maka biasanya dilakukan bergiliran dari rumah satu ke rumah yang lain.

\section{Makna Simbolis}

Dari serangkaian bahan makanan yang telah dipersiapkan mengandung makna simbolis tersendiri sebagai berikut.

a. Sego gurih dan ingkung atau yang disebut dengan rasulan (rosul) mengandung makna sebagai penghormatan kepada Rasulullah dengan berharap mendapatkan safaatnya.

b. Nasi golong yang berbentuk bulat dengan jumlah yang berbeda-beda mengandung makna bahwa bentuk bulat menandakan perjalanan hidup manusia yang terkadang ada di atas dan berada di bawah. Dibentuk dengan beberapa jumlah berdasarkan tujuannya, yaitu Golong 2 simbol siang dan malam, golong 5 simbol Pasaran Jawa, golong 7 simbol hari jawa, golong 9 simbol wali songo.

c. Buceng Kuat adalah nasi putih yang dibentuk layaknya gunung (meruncing ke atas), yang memiliki makna agar kuat/kokoh seperti gunung.

d. Jenang abang/sengkolo adalah tepung beras dimasak dan diberi gula merah. Maknanya agar dijauhkan dari musibah dan didekatkan dengan keselamatan.

e. Brokohan adalah nasi putih dengan sayur dan lauk pauk di atasnya. Disebut brokohan agar mendapatkan berkah dari Tuhan Yang Maha Esa.

f. Sayur kluwih adalah sayuran kluwih atau cempedak yang diberi bumbu dan santan kelapa dengan harapan agar lebih banyak membawa rejeki.

g. Dawet adalah jenis minuman yang memiliki butiran-butiran di dalamnya. Seperti halnya dawet yang dalam proses pembuatanya apabila diberi air bertambah banyak sehingga muncul harapan sapi yang dipelihara akan bertambah banyak

Pada tahun 2011 dilaksanakan dua kali tradisi Uyen Sapi, yaitu pada hari Jum'at 25 Pebruari 2011 dan Jum'at 23 September 2011. Tradisi Uyen Sapi merupakan kewajiban bagi masyarakat di Desa Jonggol. Banyak dari mereka yang beranggapan bahwa jika tidak melakukan tradisi sebagaimana mestinya akan berdampak kurang baik terhadap kehidupannya. Adat tata cara dalam tradisi sendiri pada dasarnya ditujukan ke dalam satu hal tujuan hidup yaitu selamat dengan cara memanjatkan doa kepada Tuhan Yang Maha Esa.

Masyarakat Jawa beranggapan bahwa binatang sapi merupakan lambang $\mathrm{Si}$ Raja Kaya. Ini dapat dilihat bahwa binatang sapi memiliki nilai komersial yang lebih mahal dibandingkan dengan binatang ternak 
lainnya, sehingga bagi seseorang yang mempunyai ternak sapi dapat bersyukur dengan cara melakukan sedekah makanan dan berbagi dengan lingkungan sekitar dengan cara selamatan yang tertuang dalam tradisi Uyen Sapi (Wawancara dengan Jaimin, 28 Pebruari 2011).

Masyarakat di Desa Jonggol berpendapat apabila tidak dilakukan tradisi Uyen Sapi akan berpengaruh buruk terhadap kondisi ternak sapi, bisa sapi tersebut mengalami sakit bahkan sampai meninggal (Wawancara dengan Ginah, 28 Pebruari 2011). Kepala Desa setempat tidak menganjurkan untuk melaksanakan tradisi Uyen Sapi. (Wawancara dengan Marsono, 27 Pebruari 2011). Sebagian besar masyarakat di Desa Jonggol melaksanakan tradisi Uyen Sapi, kecuali sebagian kecil dari generasi muda. Mereka tidak melakukan tradisi Uyen Sapi karena orang tua sudah melakukannya (Wawancara dengan Sutrisno, 18 April 2011).

\section{Pembahasan}

Kehidupan keluarga Jawa mementingkan tujuan kebahagian yang wujudnya antara lain adalah selamat tidak ada gangguan apapun. Itulah sebabnya keluarga Jawa banyak disibukkan dengan berbagai selamatan yang harus diselenggarakan. Selamatan merupakan bentuk ritual inti dalam sinkretisme unsur-unsur kebudayaan India, Islam, dan pribumi (Geertz, 1992: 77).

Sama halnya dengan upacara selamatan yang lain, tujuan selamatan pada tradisi Uyen Sapi adalah agar terhindar dari segala musibah dan berharap agar selamat serta membawa berkah bagi keluarga yang menyelenggarakan. Makanan yang terdiri dari hidangan-hidangan yang dipersiapkan secara khusus masing-masing melambangkan sebuah konsep religius tertentu. Setiap makanan yang dibuat mempunyai makna yang berbeda-beda, namun secara garis besar ditujukan kepada Tuhan Yang Maha Esa dengan harapan akan membawa hidup ke arah yang lebih baik.

Pada tradisi Uyen Sapi terjadi perubahan pada tujuannya. Pada zaman kebudayaan Hindu, tradisi ini dilakukan untuk menghormati sapi yang dianggap sebagai binatang suci yang harus dihormati dan tidak dibenarkan untuk membunuhnya. Masuknya kebudayaan agama Islam merubahnya tujuan utama menjadi bersedekah, bersyukur terhadap Tuhan Yang Maha Esa dengan berbagi makanan kepada warga sekitar. Pada masyarakat Jawa, sapi merupakan lambang Si Raja Kaya sehingga ketika seseorang mampu berternak/ memelihara sapi harus memberikan sedekah sebagai ucapan syukur atas rezeki yang telah dilimpahkan oleh Tuhan.

Dalam konteks kekinian, sapi memainkan peranan vital dalam konteks ekonomi dan ekologi. Dalam konteks ekonomi, daging dan hasil susu sapi dapat diperjualbelikan dan menjadi minuman yang menyehatkan. Dalam konteks ekologi, kotoran sapi sangat berharga bagi petani yang berfungsi sebagai pupuk, sebagai bahan bakar dalam memasak dan apabila dicampur dengan air untuk merekatkan dapat dijadikan sebagai bahan lantai rumah. Selain itu sapi dapat dijadikan sebagai binatang penarik dalam pembajakan disawah.

Pelestarian tradisi Uyen Sapi terbukti tetap terjaga hingga saat ini karena keterlibatan dari dalam masyarakat, terutama generasi tua. Bukti nyatanya bahwa masyarakat masih melaksanakan tradisi adalah pada saat proses tradisi berlangsung peran generasi tua lebih dominan dibandingkan para generasi muda.

Secara substansi, tradisi Uyen Sapi mengandung nilai-nilai yang dapat 
mendukung integrasi sosial, yaitu saling berbagi, kebersamaan, dan gotong royong sehingga penting untuk dilestarikan. Upaya pelestarian tradisi Uyen Sapi secara internal dilakukan oleh masyarakat sendiri dari generasi yang satu ke generasi selanjutnya. Pemahaman akan nilai-nilai yang terkandung dalam tradisi Uyen Sapi akan menumbuhkan kesadaran akan makna dalam tradisi tersebut seperti melalui upaya untuk mengikutsertakan semua generasi baik generasi tua maupun muda dalam upacara tradisi Uyen Sapi. Selain itu berkembangnya mitos rasa takut apabila tidak menjalankan sebuah tradisi akan membawa dampak buruk bagi kehidupan mereka serta tradisi lisan, yaitu dari mulut ke mulut, melalui percakapan sehari-hari tentang tradisi Uyen Sapi dari generasi tua ke generasi muda.

Faktor eksternal adalah dari lembaga pemerintahan terutama pemerintah daerah bidang kebudayaan untuk mendukung setiap kegiatan masyarakat dalam rangka melestarikan budaya lokal. Misalnya dengan melibatkan pemerintah setempat dalam kegiatan tradisi Uyen Sapi sebagai tamu undangan. Selain itu dapat dilakukan dengan mendaftarkan kebudayaan tradisi Uyen Sapi kepada Dinas kebudayaan dan Pariwisata Daerah setempat sebagai kebudayaan lokal agar mendapatkan pengakuan, sehingga kebudayaan tersebut tetap terjaga.

Permasalahan yang terjadi saat ini adalah kurangnya antusias generasi muda dalam ikut berpartisipasi pada tradisi Uyen Sapi. Hal ini disebabkan oleh beberapa hal, antara lain banyak generasi muda yang masih tinggal serumah dengan orang tua meskipun mereka telah berkeluarga sehingga muncul pendapat ketika orang tua sudah melaksanakan tradisi Uyen Sapi maka mereka tidak perlu melakukannya.
Sosialisasi yang lebih intensif kepada generasi muda menjadi penting dengan cara mengundang generasi muda untuk mengikuti Uyen Sapi, memberi peran tertentu generasi muda misalnya dalam pembagian ingkung dan menganjurkan generasi muda untuk melaksanakan tradisi Uyen Sapi meskipun orang tua sudah melakukannya.

Masalah lain adalah adanya kecenderungan pelaksanaan tradisi Uyen Sapi hanya sebagai rutinitas kegiatan yang harus dilakukan oleh masyarakat, sedangkan makna-makna yang terkandung di dalamnya kurang dipahami. Jika dibiarkan demikian akan menggoyahkan tradisi ini untuk dapat dilestarikan mengingat faktor-faktor yang menyebabkan perubahan sosial dan kebudayaan semakin kompleks, antara lain mobilitasi penduduk, berbagi dampak dari inovasi di bidang teknologi informasi, dan pertentangan/konflik dalam masyarakat. Sosialisasi dan internalisasi nilai-nilai yang terkandung di dalamnya menjadi semakin penting baik secara internal maupun eksternal.

Pengaruh tradisi ini terhadap kehidupan sosial masyarakat di Desa Jonggol adalah saling berbagi, gotong royong, dan kebersamaan. Hal ini terbukti pada saat selamatan berlangsung (baik untuk tamu undangan maupun tamu yang tidak bisa mengikuti selamatan), yakni dengan berbagi makanan yang sebelumnya telah diberi doa dengan tujuan bersedekah. Kebersamaan pada saat selametan yaitu tanpa memandang derajat seseorang baik tinggi maupun rendah dibagikan makanan secara adil dan merata serta gotong royong pada saat pembuatan makanan oleh warga sekitar terutama kaum perempuan.

Saat ini semakin jarang ditemui lingkungan masyarakat yang masih memiliki nilai-nilai saling berbagi, kebersamaan, dan gotong royong terutama bagi masyarakat yang tinggal di daerah perkotaan. Hal ini 
banyak disebabkan karena banyak faktor, salah satunya faktor kesibukan pekerjaan yang berbeda-beda. Berbeda halnya dengan masyarakat yang tinggal di daerah pedesaan yang mayoritas bekerja sebagai petani yang mayoritas dalam pengerjaan pertanian dilakukan dengan bersama-sama.

Secara garis besar makna tradisi Uyen Sapi mengajarkan kepada manusia untuk bersyukur terhadap nikmat yang diberikan oleh Tuhan Yang Maha Esa, dengan cara saling berbagi/bersedekah makanan terhadap warga masyarakat. Nilainilai yang terkandung dalam keluarga Jawa dan masyarakat Jawa masih sesuai dengan perkembangan zaman. Ini terbukti masih dilakukannya tradisi Uyen Sapi hingga saat ini.

Saling berbagi dengan warga masyarakat sekitar baik dalam hal makanan maupun pekerjaan. Dalam hal makanan misalnya berlaku adil terhadap setiap undangan baik yang dapat menghadiri maupun yang tidak dapat menghadiri undangan, dengan membagikan berkat makanan sesuai jumlah tamu yang diundang termasuk yang tidak bisa datang juga diberikan berkat makanan. Disini lebih ditekankan pada kuantitasnya dibandingkan kualitas makanan, meskipun makanannya sederhana namun semua bisa menikmati dan dibagi rata.

Guyub merupakan akar tradisi Jawa yang melekat. Dimaknai sebagai kerukunan, kebersamaan, akur, senasib dan seperjuangan. Istilah kekiniannya dapat disebut sinergi. Dengan guyub pula persoalan sulit dapat diurai secara bersama dalam satu titik temu, seiya sekata. Spirit guyub menanggalkan segala perbedaan untuk satu tujuan. Guyub bisa tercapai jika kepentingan-kepentingan pribadi untuk tujuan sendiri dibuang jauh. Guyub menemukan ruhnya di tanah Jawa dalam wujud gotong royong.
Sifat gotong royong masih kental dirasakan di Desa Jonggol. Ini terbukti dari setiap kegiatan masyarakat lebih mengutamakan kepentingan umum dibandingkan kepentingan pribadi. Misalnya dalam kegiatan tradisi Uyen Sapi, dalam mempersiapkan makanan untuk acara selametan, para kaum perempuan terutama ibu-ibu datang langsung membantu tanpa diminta bantuan terlebih dahulu. Kebersamaan yang terjadi dalam serangkaian proses tradisi Uyen Sapi semakin mempererat rasa persaudaran dalam lingkungan sekitar sehingga menciptakan kondisi lingkungan yang lebih dekat antara warga satu dengan warga yang lain. Guyub dan gotong royong merupakan wujud kepedulian sosial yang telah menjadi budaya.

Mayarakat di Desa Jonggol termasuk ke dalam masyarakat tradisional. Masyarakat tradisional adalah masyarakat yang kehidupannya masih banyak diwarnai oleh adat istiadat lama. Adat istiadat merupakan kebiasaan turun temurun yang diwariskan oleh generasi ke generasi terdahulu yang masih dilakukan oleh masyarakat baik berupa benda material maupun gagasan secara tidak tertulis sebagai kontrol atas tingkah laku atau sikap manusia sebagai warga suatu masyarakat.

Masyarakat tradisional di dalam melangsungkan kehidupannya berdasarkan pada cara-cara atau kebiasaan-kebiasaan lama yang masih diwarisi dari nenek moyangnya. Kehidupan mereka belum terlalu dipengaruhi oleh perubahanperubahan yang berasal dari luar lingkungan sosialnya. Kebudayaan masyarakat tradisional merupakan hasil adaptasi terhadap lingkungan alam dan sosial sekitarnya yang menghasilkan kearifan lokal yang penting bagi keberlangsungan kehidupan masyarakatnya. 


\section{Simpulan dan Saran}

\section{Simpulan}

a. Tradisi Uyen Sapi dilaksanakan pada hari Jumat Wage Wuku Wuye yang dianggap hari kelahiran sapi. Prosesi diawali dengan ikrar hajat oleh tokoh adat dalam Bahasa Jawa, dilanjutkan doa oleh tokoh agama dalam Bahasa Arab, pembagian bahan-bahan selamatan secara merata kepada warga yang diundang, termasuk warga yang tidak bisa datang, dan terakhir pemberian minuman dawet kepada sapi di kandang.

b. Bahan-bahan selamatan mengandung makna simbolis tersendiri. Makna simbolis tersebut tidak lepas dari ekspresi harapan dan doa syukur, keselamatan, dan keberkahan dari rizki yang diberikan Tuhan.

c. Tradisi Uyen Sapi menjadi media bagi masyarakat untuk merajut integrasi sosial masyarakat di tengah arus silang budaya global.

d. Tradisi Uyen Sapi merupakan warisan budaya dari zaman kebudayaan Hindu yang telah mengalami akulturasi dengan kebudayaan Islam. Pada masa Hindu, tradisi tersebut bertujuan untuk menghormati sapi sebagai binatang suci, sedangkan pada masa Islam bertujuan sebagai wujud rasa syukur terhadap Tuhan Yang Maha Esa. Tradisi tersebut terus dilestarikan oleh masyarakat pendukungnya dan dengan keterlibatan pemerintah daerah setempat.

\section{Saran}

a. Bagi masyarakat di Desa Jonggol tidak hanya sebagai rutinitas semata, melainkan benar-benar dipahami kebermaknaannya dalam merajut integasi sosial dan sebagai alat penyaring kebudayaan luar yang cenderung mengikis rasa kebersamaan dan gotong royong. b. Bagi Dinas Kebudayaan Dan Pariwisata Daerah setempat agar memperhatikan pelestariannya sebagai salah satu akar dari kebudayaan nasional. 


\section{DAFTAR PUSTAKA}

Astrid S. Susanto. 1979. Pengantar Sosiologi dan Perubahan Sosial, Bandung: Bina Cipta.

Budiono Herusatoto. 2008. Simbolisme Jawa. Yogyakarta: Ombak.

Geertz, Clifford. 1992. Kebudayaan dan Agama. Yogyakarta: Kanisius.

Lucas Sasongko Triyoga. 1991. Manusia Jawa dan Gunung Merapi, Persepsi dan Sistem Kepercayaanya. Yogyakarta : Gadjah Mada University Press.

Koentjaraningrat. 1992. Beberapa Pokok Antropologi Sosial. Jakarta : PT Dian Rakyat.

1997. Manusia dan Kebudayaan di Indonesia. Jakarta : Uni Press.

Maryaeni. 2005. Metode Penelitian Kebudayaan. Jakarta : PT Bumi Aksara

Nyoman Kutha Ratna. 2010. Metodologi Penelitian Kajian Budaya dan IImu Sosial Humaniora pada Umumnya. Yogyakarta: Pustaka Belajar.

Purwadi. 2007. Pranata Sosial Jawa. Yogyakarta : Cipta Karya

Siagian, Seno Harbangan. 1986. Agamaagama di Indonesia. Semarang: Satya Wacana.
Sidi Gazalba. 1974. Antropologi Budaya. Jakarta : Bulan Bintang.

Sihombing, O.D.P. 1962. India Sedjarah dan Kebudayaannja. Bandung : Sumur Bandung.

Soerjono Soekanto. 1990. Sosiologi Suatu Pengantar. Jakarta : PT. Raja Grafindo Persada.

Sutopo, HB. 2006. Metodologi Penelitian Kwalitatif Dasar Teori dan Terapannya dalam penelitian. Surakarta: Universita Sebelas Maret

Sztompka,Piort. 2008. Sosiologi Perubahan Sosial. Jakarta : Prenada.

Team Penyusun Penelitian dan Kebudayaan Daerah Pusat penelitian Sejarah dan Budaya depdikbud. 1977. Adat Istiadat Daerah Istimewa Yogyakarta. Jakarta.

Zoetmulder. 2006. Kamus Jawa Kuno Indonesia. Jakarta: Gramedia Pustaka Utama 